\title{
One Model for Creating a Career Ladder for Library Support Staff
}

\author{
Jane Fama, MSLS, AHIP \\ Associate Director, Library Operations \\ Lamar Soutter Library \\ University of Massachusetts Medical School \\ 55 Lake Avenue North \\ Worcester, MA 01655 \\ jane.fama@umassmed.edu
}

Elaine Martin, DA

Director

Lamar Soutter Library

University of Massachusetts Medical School

55 Lake Avenue North

Worcester, MA 01655

elaine.martin@umassmed.edu 


\begin{abstract}
This article describes a unique career ladder model for library support staff. Major components include a promotion in place opportunity based on specified achievement levels, competencies, cross training, and measurable evaluation. The authors discuss the background, development, and program description of the career ladder model.
\end{abstract}

\title{
INTRODUCTION
}

New trends such as the move to a single service point, institutional repositories, evidence based medicine, the digital library, and social networking challenge libraries to remain relevant to their users. These trends have a common theme: change. Business as usual for most libraries is a thing of the past. ${ }^{1}$ Such trends also affect the role that librarians and support staff play. At a recent Medical Library Association conference, for example, participants spent considerable time discussing how library professionals must become more in touch with the needs of their institutions and become integrated into their education, research and service missions. ${ }^{2}$ Attendees agreed that the roles of the library and the librarian are being redefined, propelling the librarian out of the physical space called "library" and into the academic home of the patron. If the librarians are leaving the library, then who is servicing those users who come into the library’s physical space? The managers at the Lamar Soutter Library (LSL) of the University of Massachusetts Medical School, Worcester, see this as the new job of the support staff: to take over many of the duties traditionally performed by professionals. Little by little, and in some cases, all at once, support staff are required to take on more responsibility. 
Driven by the needs of patrons, changes in the types of services and collections provided by the Lamar Soutter Library led the Management Team to re-examine and redefine the support staff model. The changing roles of librarians caused the elimination of the reference desk and the addition of a single service desk served only by the support staff. The purchase of electronic-only journals and e-books eliminated some traditional support staff roles. When the library no longer checked in print journals, there was no longer a need for one support staff dedicated to that task. Rather, as the Management Team defined new services and collections, the need for a higher level support staff member with the ability to handle functions in multiple areas of the library became evident. As the librarians became specialists, support staff needed to become generalists.

Coinciding with the trends and changes impacting libraries in general, and in an attempt to create a planned, proactive response, the Lamar Soutter Library embarked on a year long strategic planning process in which all staff participated. Not surprisingly, one of the major themes that emerged was that support staff wanted a way to develop and grow into their newly defined jobs. Support staff had no way to advance in the current personnel system. Since staff were taking on more responsibility with higher level duties, then adequate training and compensation were needed.

The Management Team addressed the concerns that staff expressed as part of the strategic planning process by developing a new model for defining, training, and promoting support staff. Managers described the initial problem in terms of a set of questions: 1) How do support staff get promoted in libraries? 2) How can staff working in multiple areas of the library be compensated 
fairly? 3) How do staff acquire the knowledge and skills needed to work in the modern library? 4) What should support staff job descriptions include in them? 5) What objective evaluation criteria can be developed to quantify staff success and therefore, eligibility for promotion? The new LSL support staff model was developed to answer these questions and take into account the trends, changes, and role redefinition taking place in the modern academic library.

This paper 1) describes the model for support staff that allows them growth within the library and provides a promotion in place plan; 2) outlines the rationale for implementing the model; 3) explains how the model is different from other models found in the library literature and 4) makes the case for a competency-based model for support staff development and evaluation. Academic libraries throughout the country face the same issues as those confronting the LSL, a

medium sized medical library. ${ }^{3}$ However, no other library has reported on the development of a support staff model that includes a combination of training across library functional areas, promotion, and evaluation criteria. Therefore, the Lamar Soutter Library’s support staff model for promotion, training and development described in this paper could benefit other types of libraries not just academic health sciences libraries.

\section{BACKGROUND}

The Lamar Soutter Library serves the University of Massachusetts Medical School, which is part of the state-wide university system in Massachusetts. The library is stand-alone and does not report administratively to any of the other academic libraries in the system. The Medical School campus is made up of a School of Medicine, a Graduate School of Nursing, and a Graduate School of Biomedical Sciences and is affiliated with a large hospital network. The library's 
primary clientele are the students, faculty, and staff of the medical school and its clinical affiliates. Unlike many medical libraries, the library is open to the public. Open seven day per week for a weekly total of 99.5 hours while being closed only 6 days per year definitely presents a staffing challenge! There are 22 support staff and 23 professionals with MLS or other advanced degrees.

Support staff at LSL work in four areas of the library - Public Desk, Interlibrary Loan, Resource Management (technical services), and Technology Initiatives and Support (systems). The support staff role in the library was defined aptly by the American Library Association Committee on Education's Task Force for Review of the Criteria for Programs to Prepare Library Technical Assistants as persons who, "carry out operations and services essential to effective functioning of the organization... . The tasks, performed as supportive staff to Associates and higher ranks, follow established rules and procedure, and include, at top level, supervision of such tasks.” ${ }^{4}$ Over the years at LSL, support staff roles had become very specialized. One person was responsible for binding, one for journal check-in, another for ILL borrowing, and so forth. Staff responsible for the circulation duties worked only in circulation. Although this model worked well for many years, changes in technology, the shift from print to electronic resources, and budget constraints eventually caused the library to reexamine, redistribute and even eliminate some functions and services.

Prior to the career ladder program described below, library support staff job descriptions were assigned a numeric grade (e.g. 12, $13 \ldots$... 16) following the UMMS human resources classification system. The grade determined the compensation scale for that position. There were 
two problems with this system. First, non-technical services staff job descriptions were graded traditionally lower than those in technical services. As staff in all areas of the library became more dependent on technology to perform their jobs, grading staff differently because of the unit they worked in became irrelevant. Secondly, supervisors’ only means of promoting high achievers (moving them to a higher pay grade) was to change the wording of the job description and create another job. Supervisors constantly tweaked the wording of positions - making them more "specialized" until the tweaking would be enough to upgrade the job - thus giving the employee a "back door" promotion. The result was that the library became full of specialized support staff positions which were in some cases graded differently, seemingly for arbitrary reasons. The notion of pay for performance became blurred, and tightly defined job descriptions limited the ability of managers to cross train and redistribute staff from one area of the library to another.

\section{LITERATURE REVIEW}

The library literature sorely lacks materials that address the changing roles of support staff in the library. Although authors call for the need for training and rewarding support staff for higher level positions, there are few articles citing specific, working career ladder programs. Whereas much of the literature echoes the problems related to staff compensation and rewards, it offers

few solutions. The Lamar Soutter Library support staff career model builds on the literature and offers a concrete operational program combining training, development, evaluation criteria and promotion. 
In 1989, Library Journal defined the support staff issue as "the” issue of the nineties, saying, “ Library support of development opportunities for all staff at all levels will be the fundamental issue of the coming decade. ${ }^{, 5}$ As stated in Library Personnel News, as early as 1995 support staff were taking on the roles of librarians but not necessarily being compensated. In short, support staff are getting more responsibility but not more money. ${ }^{6}$ In the 1998 Library Journal, Anne Woodsworth discusses the plight of library assistants and concluded, "The biggest problem of all is that there is virtually no career path for an LA."”

Although support staff issues were a major concern in the nineties, many libraries were still struggling with these questions at the turn of the century. In the 2003 Journal of Academic Librarianship, Frada Mozenter et al wrote, "the literature reflects that for the most part the training of paraprofessionals has not kept pace with the use of paraprofessionals.” The authors asked the all important questions, "What competencies should be required and which training methods are most effective?” ${ }^{8}$ Also in 2003 the $3^{\text {rd }}$ Congress on Professional Education (COPE III) meeting focused on Library support staff. ALA executive director Keith Michael Fiels said, "We need to stop ignoring our support staff; instead we need to train them, we need to recognize them." Some of the major issues discussed and determined to be necessary at the congress were certification, career ladders, and pay equity. The need for training is recognized, combined with the next step - recognition - the first step toward advancement. ${ }^{9}$ On a local level, members of the Tennessee Library Association Paraprofessional Roundtable conducted a survey to identify support staff issues in 2004. Not surprisingly, the results of this survey echoed what was being discussed by COPE. The five major concerns identified were: 1 . Compensation not appropriate to the level of education, 2. Career ladders lacking, 3. Little access to continuing education or 
training opportunities, 4. Lack of paraprofessional certification program, and 5. Lack of recognition for contributions. ${ }^{10}$

The authors found only one medical library and two academic libraries reporting the development of career ladder programs for support staff. Initiated in 1996, the Eskind Biomedical Library at Vanderbilt system is based somewhat on a pay-for-knowledge compensation plan. Support staff positions were renamed health information analysts (HIAs) and are rewarded "on the basis of the inventory of skills or knowledge areas they have acquired rather than for specific jobs performed.” HIAs must achieve certain career milestones for promotion, including training to become familiar with areas of the library not directly associated with their own jobs. Their accomplishments are tracked in individual portfolios. ${ }^{11}$ Influenced by the Vanderbilt model, Auburn University Libraries developed a career ladder based on satisfactory job performance, increased competencies, training, and achievement of department specific criteria. This was a significant philosophical change since previously, support staff were classified "solely on the responsibilities of the position and not on the employee." ${ }^{\text {, }}$ A subsequent article published four years later identified the lack of objective evaluation criteria for "higher level responsibilities" as a problem with the Auburn program. ${ }^{13}$ What distinguished the University of Connecticut Career Ladders Program for library support staff from the Vanderbilt and Auburn systems was their development of five criteria for advancement along with the creation of a peer review committee, whose role it is to review qualifications of individuals and make recommendations for promotion. The five criteria: 1. Years in service, 2. Leadership and initiative , 3. Critical thinking , 4. Distinctive knowledge and skills, and 5. Commitment to community provided the basis for which "Paraprofessionals may move among 
three tiers-developing, accomplished, and mastery - within each job classification. Movement is based on documentation contained in the career portfolio and is evaluated by a Peer Review Committee (PRC), which then makes recommendations to the library administrator.”14

The issues surrounding support staff compensation and promotion reflected in the library literature remained constant during the last 20 years and continue to be relevant today. 515471612 910 Despite this seemingly lack of progress, three academic libraries, the libraries at Auburn University, Vanderbilt Medical Center and the University of Connecticut, reported developing alternative career ladders that created promotional pathways for their support staff. Features of these early systems provided the framework for the LSL support staff career ladder program. The LSL model differs from these earlier models in that it provides for objective evaluation criteria for determining staff's progress. In addition, unlike earlier models based on department specific knowledge or familiarization with other library areas, the LSL model emphasizes formal development of staff expertise across library functional areas. Thus, while providing for staff growth, LSL also takes into consideration library needs and positions the library to better utilize its resources.

\section{PROGRAM DESCRIPTION}

The LSL career ladder program offers support staff an opportunity to develop, train, and advance in multiple areas of library work. The program is structured around three components: education, years of service and cross functional training. Through a combination of education, years of service, and training, support staff may be promoted to the next higher level grade and receive a salary increase that is added to their base pay. See Figure 1. 
The Levels Program was designed to work with the university's current annual review process. During this process, managers review and document achievement of the past year and set goals for the coming year for each employee. Goals include a development plan for each employee that guides the employee through the stages of the areas of responsibility as set by the Levels Program. The development plan in particular specifies training opportunities and skill development along with a time table needed to achieve the next stage. Each employee's updated portfolio describing his progress across all areas of responsibility is attached to the evaluation form and submitted to Human Resources. Evaluation ratings are determined by the employee's progress in achieving goals and by the employee's overall performance. Rating categories are Does Not Meet, Needs Improvement, Meets, Exceeds, and Outstanding. Ratings are tied to the merit raises, which are set each year by the university and the union contract.

The timing of promotion via the Levels Program, however, is not tied to the yearly review. When an employee achieves the promotion criteria set by the Levels Program, he is recommended for promotion by the supervisor regardless of where we are in the annual review cycle. The promotion and subsequent raise in pay is in addition to any compensation previously realized via merit raise.

A definition for, and a description of, each of the Levels Program components follows, along with a description of the promotion and evaluation methods aspects of the program.

Promotion: The new model for the LSL career ladder program can be simply expressed by the formula: Education + Years of Service + Cross Functional Training $=$ Promotion, where 
promotion means moving to a higher level of grade and pay. For example, all employees begin with the title of Library Assistant 1 and can progress through the program to Library Assistant 2 by satisfying all three pieces of the equation. The highest level of promotion is attainment of Library Assistant 3. Although employees must pass through each component part to achieve promotion, the depth and breadth of experience and educational level changes depending on whether an employee is striving to become a library assistant 2 or 3 . In addition, there are specific objective evaluation criteria and methods for documenting achievement required for promotion.

Education: The minimum educational requirement for a library assistant is a college degree beyond the high school diploma. The entry level Library Assistant 1 requires an Associate's Degree while a Bachelor's Degree is required for promotion to Library Assistant 3.

Years of Service: Years of service refers to time spent working at the Lamar Soutter Library. Previous experience in another library or related field may have played an important role in the initial hiring decision, but does not factor into promotion. Two years of service are required for promotion to Library Assistant 2; five years are required for Library Assistant 3.

Cross Functional Training: Cross functional training does not mean that staff are simply trained to do a variety of library tasks. Cross Functional Training refers to a matrix of intertwined sectors called Areas of Responsibility, Competencies, Achievement Stages and Frameworks. Areas of Responsibility correspond to library functional areas. Currently there are four functional areas within the LSL: Public Desk; Interlibrary Loan; Resource Management and Technology 
Initiatives and Support. Upon being hired, Library Assistant 1's are assigned one area of responsibility. However, what makes this program unique is that in order to be promoted, staff must be trained across library functional areas. Cross functional training begins when a staff member has completed training in his assigned area of responsibility or when deemed necessary by departmental needs.

Competencies refer to the knowledge and skills that define librarianship as it applies to support staff regardless of their assigned area of responsibility. The LSL managers identified 5 competencies: supervision, leadership and initiative, critical thinking and problem solving, distinctive knowledge and skills, and commitment to service and community. Competencies map to Achievement Stages. There are three Achievement Stages—developing, accomplished and mastery. Each stage requires increasing competency or skill and knowledge. At minimum, all staff members are expected to both demonstrate the competencies defined in the accomplished stage within their assigned area of responsibility and demonstrate competencies at the developing stage in other functional areas of the library in order to reach promotion. Figure 2 depicts the relationship between competencies and achievement stages.

Frameworks are the tasks or duties within each achievement stage. Frameworks concretely illustrate a staff members’ ability to demonstrate that he/she has reached either developing, accomplished or mastery of their assigned area of responsibility. Each framework has an objective measure of evaluation of success assigned to it. Figure 3 depicts an example of one framework and its evaluation criteria.* 
Evaluation methods: How do managers ascertain that frameworks have been met and that staff are ready to be promoted? The program includes six evaluation methods: case study, observation, written assessment, role playing, self evaluation and customer evaluation. In addition to objective criteria for evaluation of frameworks, one or more of these methods is used to certify that a support staff member has achieved the appropriate stage and therefore, is ready to apply for promotion. Managers meet with support staff on a regular basis to track their progress via one of these evaluation methods and record accomplishments in a portfolio binder. The portfolio is actually a table of frameworks - duties and tasks - for each area of responsibility. An individual's portfolio will contain tables for all areas, although the person may be concentrating on only one or two areas. Next to the frameworks is a column for date of certification, where the manager dates and initials that the individual has accomplished a particular framework. The portfolio enables the manager and the staff member to see a snapshot of where a person is in the training process at any time and how close an individual is to qualifying for promotion. Portfolios are tracked electronically, but can be placed in a binder for the individual's own use. Evaluation is identical for each person for any one framework. The idea is to have objective evaluations that can be repeated for each staff member. Evaluation is done individually, although training may be done individually or in groups.

\section{APPROVAL PROCESS}

There were three major players for whom approval was necessary before the library's career ladder program could become a reality - the Union (the support staff at LSL are unionized), UMASS Medical School Administration, and Human Resources. 
The Administration's approval was necessary because the raises that would be built into the promotions needed to be added to the library's existing personnel budget line. In addition, the program's new job descriptions detailed skills and competencies at a higher level than the current job descriptions for support staff. Thus, the Level's Program proposed upgrading the support staff positions from the current HR grades 12 - 16 to grades 15, 17, and 41 for levels 1-3 respectively. Current employee salaries would have to be increased at least to the new minimum of level 1. To obtain approval for these budget increases, the authors approached administration early on in the process when the basic outline of the plan had been developed. Data was essential to justifying salary adjustments and the recommended new salary ranges for all the levels. The authors gathered the salary data by contacting major medical libraries in New England and across the country to compare their salary ranges for paraprofessionals with the proposed ranges for LSL. The analysis included data from six New England medical schools, and twelve top U.S. medical schools outside of New England. It was clear from the data that LSL current support salaries fell well below the average ranges and that the proposed salary ranges were comparable to the current ranges of top U.S. medical schools. Figure 4 is a summary, condensed to three ranges for easy comparison, of the data presented to Medical School Administration. After reviewing the data, Administration approved the funding for the program. Once administrative approval was expected, the authors approached Human Resources (HR). Human Resource approval was necessary because, as previously mentioned, UMASS Medical School operates on a grading system, and whatever plan the library instituted had to fit into that grading system. Although HR responded positively to the concept of a career ladder program for support staff, HR staff were not initially convinced that library support staff performed duties more complex than those of clerical assistants working elsewhere in the medical school. The 
compensation data along with the new job descriptions eventually convinced them. As a result of HR's buy-in, the new grades and corresponding job descriptions were accepted, and most staff received raises as the program was implemented.

Although Union approval was not technically needed to move ahead with this program, the authors knew their support would be invaluable to the success of the program. However, the managers did not want the union to dictate the details of the program. The initial meeting with the union gave the authors a chance to present the outline of the program along with the benefits of the program to their members. Subsequent meetings gave the union a chance to give feedback about any concerns. One of the union representatives was a member of LSL's support staff. Having a member of the LSL staff on the union team was an advantage as the managers felt that if we could get his support, he could influence other support staff.

Approvals did not come after only one meeting with each of these groups. Throughout the process, the authors met several times with representatives from each group, bringing more detailed information each time. The meetings with these parties were concurrent not linear. Each of the groups immediately recognized the intrinsic value of a career ladder program for support staff. After a year long process we had approvals in place from Administration and Human Resources, and we had the full support of the Union.

\section{CONCLUSION}

The development of a career ladder program for support staff in academic health sciences libraries is not an easy task. There are many hurdles to over come such as the role definition of 
high level clerical work in a library, the need for higher minimum educational qualifications for new recruits, and the development of strong, quantitative evaluation frameworks and methods for measuring successful completion of tasks. Earlier career ladder models that were reported in the literature lacked objective evaluation methods for determining staff progress and focused staff training on developing department specific knowledge and skills. The LSL, building on these models, instituted a comprehensive, pay for performance, career ladder program that is unique with its emphasis on formal cross functional training and six objective evaluation methods. Currently the program is being considered by the HR department and the Union as a possible model to be adapted to other units throughout the medical school.

To date, all library support staff are part of the Levels Program, and two of them are almost ready to be promoted to the next level (Level 2). The library is in the process of recruiting its first new employee under the program. (All other staff had been grandfathered in). This will give us our first opportunity to work with an employee from the recruitment process, through the hiring process, through orientation, training and on boarding into level 1 and beyond. The authors are confident that the LSL career ladder program prepares and rewards existing and new staff for the challenging work environment of the $21^{\text {st }}$ century library.

*For a complete list of frameworks, contact the authors. 


\section{References}

1. Paula Warnken. "MANAGING TECHNOLOGY New Technologies and Constant Change: Managing the Process." Journal of Academic Librarianship 30, no. 4 (2004): 322-327.

2. Frances H. Lynch, and Rachel R. Walden. "Proceedings, 108th Annual Meeting Medical Library Association, Inc. Chicago, Il May 16-21, 2008." Journal of the Medical Library Association 97, no. 1 (2009): E1-E41.

3. Teresa Strasner. "Continuing Education Needs for Technical Services Paraprofessionals in Academic Libraries." Colorado Libraries 26, no. 1 (2000): 22-24.

4. Task Force for Review of the Criteria for Programs to Prepare Library Technical Assistants, American Library Association Committee on Education. "Criteria for Programs to Prepare Library Technical Assistants." American Library Association, 1998.

5. "Career Development: Defining the 'Issues of the Nineties'." Library Journal 114, no. 12 (1989): 52-55.

6. "Librarian and Support Staff Roles Need Clearer Definition." Library Personnel News 9, no. 5 (1995): 3-4.

7. Anne Woodsworth. "The Plight of Library Assistants." Library Journal 123, no. 13 (1998): 60.

8. Frada Mozenter, Bridgette T. Sanders, and Carol Bellamy. "Perspectives on Cross-Training Public Service Staff in the Electronic Age: I Have to Learn to Do What?!" Journal of Academic Librarianship 29, no. 6 (2003): 399-404.

9. "Delegates Define Sustainable Solutions for Support-Staff Issues." American Libraries 34, no. 7 (2003): 36-37. 
10. Chris Durman. "Tennessee Library Support Staff Want Equitable Compensation, Career Ladders, and Continuing Education: TLA Survey Results." Tennessee Libraries 56, no. 4 (2006): 1-18.

11. Jeffrey T. Huber, Nunzia B. Giuse, and John R. Pfeiffer. "Designing an Alternative Career Ladder for Library Assistants." Bulletin of the Medical Library Association 87, no. 1 (1999): 74-77.

12. Kerry A. Ransel, Jack D. Fitzpatrick, and Susan L. Hinds. "Advancement at Last: CareerLadder Opportunities for Library Support Staff." Technical Services Quarterly 19, no. 2 (2001): 17-26.

13. Sherida H. Downer, Kerry A. Ransel, and Jack D. Fitzpatrick. "Auburn University Libraries Career Ladder Four Years Later: Update, Outcomes, and Lessons Learned." Technical Services Quarterly 22, no. 3 (2005): 47-54.

14. Tara Ludlow Hurt, and Deborah Stansbury Sunday. "Career Paths for Paraprofessionals." Library Mosaics 16, no. 1 (2005): 8-11.

15. Jett C. McCann, Shelley E. Davis, Donna J.Trainor, D. Kay Waller, and Robert B. Greenblatt. "Restructuring Support Staff Classification Levels for Academic Health Sciences Library Positions." Bulletin of the Medical Library Association 78, no. 3 (1990): 293-301.

16. Paulette Feld. "Ala Library Career Pathways Task Force Report." Library Mosaics 12, no. 3 (2001): 10 . 


\begin{tabular}{|c|c|c|c|c|}
\hline & \multicolumn{2}{|l|}{ Level | } & \multirow[t]{2}{*}{ Level II } & \multirow[t]{2}{*}{ Level II } \\
\hline & Probation & Post-probation & & \\
\hline $\begin{array}{l}\text { Years of Service } \\
\text { within LSL }\end{array}$ & $0-6$ months & 6 month minimum & 2 years minimum & 5 years minimum \\
\hline Education & Associated Degree & Associates Degree & Associates Degree & BA or BS \\
\hline \multirow[t]{3}{*}{$\begin{array}{l}\text { Cross- } \\
\text { Departmental } \\
\text { Knowledge }\end{array}$} & $\begin{array}{l}\text { Training in } \\
\text { Developing Stage } \\
\text { of Major Area of } \\
\text { Responsibility } \\
\text { (MAR). }\end{array}$ & $\begin{array}{l}\text { Certified in the } \\
\text { Developing Stage of } \\
\text { MAR upon completion } \\
\text { of probation. }\end{array}$ & $\begin{array}{l}\text { Certified in the } \\
\text { Accomplished Stage } \\
\text { of MAR. }\end{array}$ & $\begin{array}{l}\text { Certified in the } \\
\text { Mastery Stage of MAR. }\end{array}$ \\
\hline & & $\begin{array}{l}\text { Certified in the } \\
\text { Accomplished Stage } \\
\text { of MAR within first year } \\
\text { of employment. }\end{array}$ & $\begin{array}{l}\text { Certified in the } \\
\text { Developing Stage in } \\
\text { two other Areas of } \\
\text { Responsibility. }\end{array}$ & $\begin{array}{l}\text { Certified in the } \\
\text { Accomplished Stage in } \\
\text { two other Areas of } \\
\text { Responsibility. }\end{array}$ \\
\hline & & $\begin{array}{l}\text { Begins cross- } \\
\text { departmental training. }\end{array}$ & $\begin{array}{l}\text { Continues cross- } \\
\text { departmental training. }\end{array}$ & $\begin{array}{l}\text { Certified in the } \\
\text { Developing Stage in } \\
\text { one other Area of } \\
\text { Responsibility. }\end{array}$ \\
\hline
\end{tabular}

Figure 1 - Promotion Chart 


\begin{tabular}{|c|c|c|c|}
\hline \multicolumn{4}{|c|}{ Achievement Stage Competencies * } \\
\hline & Developing & Accomplished & Mastery \\
\hline Supervision & $\begin{array}{l}\text { Works under direction. Follows written } \\
\text { procedures. }\end{array}$ & $\begin{array}{l}\text { Needs minimal direction; some guidance; } \\
\text { trains others in basic processes. }\end{array}$ & $\begin{array}{l}\text { Develops own work plan; can manage } \\
\text { departmental operations of an AR }\end{array}$ \\
\hline $\begin{array}{l}\text { Leadership and } \\
\text { Initiative }\end{array}$ & $\begin{array}{l}\text { Team member; performs duties } \\
\text { effectively. }\end{array}$ & $\begin{array}{l}\text { Makes positive contributions; takes } \\
\text { initiative. }\end{array}$ & Proactive; demonstrating leadership. \\
\hline $\begin{array}{l}\text { Critical } \\
\text { Thinking and } \\
\text { Problem Solving }\end{array}$ & $\begin{array}{l}\text { Refers problems to supervisor. Takes } \\
\text { initiative to schedule meetings with } \\
\text { supervisor. }\end{array}$ & $\begin{array}{l}\text { Contributes to problem resolution. Brings } \\
\text { problem to supervisor with possible } \\
\text { solutions. }\end{array}$ & $\begin{array}{l}\text { Resolves and implements solutions } \\
\text { independently. }\end{array}$ \\
\hline $\begin{array}{l}\text { Distinctive } \\
\text { Knowledge and } \\
\text { Skills }\end{array}$ & Performs basic duties successfully. & $\begin{array}{l}\text { Performs higher level duties successfully. } \\
\text { Adapts to change; updates knowledge of } \\
\text { librarianship and information technology; } \\
\text { demonstrates consistent application of } \\
\text { new knowledge and skills to achieve } \\
\text { efficiency and improve service. (i.e., } \\
\text { Suggests improvements in workflow.) }\end{array}$ & $\begin{array}{l}\text { Proactively acquires and applies } \\
\text { special knowledge to meet library } \\
\text { needs (cross functionally); has broader } \\
\text { library picture in mind; frequently } \\
\text { consulted by others to provide training, } \\
\text { troubleshooting or documentation. }\end{array}$ \\
\hline $\begin{array}{l}\text { Commitment to } \\
\text { Service and } \\
\text { Community }\end{array}$ & $\begin{array}{l}\text { Demonstrates ability to address } \\
\text { internal and external customer needs } \\
\text { with high standards of service } \\
\text { excellence within the operational area. } \\
\text { Beginning to establish effective } \\
\text { relationships within the institution's } \\
\text { community. }\end{array}$ & $\begin{array}{l}\text { Demonstrates ability to address internal } \\
\text { and external customer needs with high } \\
\text { standards of service excellence, matching } \\
\text { customer needs with resources } \\
\text { throughout the library. Establishes } \\
\text { effective relationships within the } \\
\text { institution's community. }\end{array}$ & $\begin{array}{l}\text { Represents and promotes the library. } \\
\text { (Serves on committees outside the } \\
\text { library.) }\end{array}$ \\
\hline
\end{tabular}

\section{Figure 2 - Achievement Stage Competencies}

*Based on the work of Hurt and Sunday. 


\begin{tabular}{|c|l|}
\hline Duty & Framework \\
\hline Retrieves Material. & Can identify all parts of a standard citation \\
\hline$\bullet \quad \begin{array}{l}\text { Retrieves journals, books, microfilm for } \\
\text { scanning from main Library and } \\
\text { storage }\end{array}$ & $\begin{array}{l}\text { 1. Can retrieve } 40 \text { journals in } 1.5 \text { hours } \\
\text { 2. Can successfully locate all material held } \\
\text { by LSL. }\end{array}$ \\
\hline $\begin{array}{l}\text { Using Voyager, can determine and } \\
\text { document why material is not } \\
\text { available. }\end{array}$ & $\begin{array}{l}\text { 1. Can search Integrated Library System to } \\
\text { locate holdings. } \\
\text { 2. Can identify parts of holdings record and } \\
\text { understands implications of holdings. }\end{array}$ \\
\hline $\begin{array}{l}\text { Basic Quin Searching Skills; can locate } \\
\text { books and journals; understands } \\
\text { holdings information }\end{array}$ & $\begin{array}{l}\text { Given a list of titles can determine with 95\% } \\
\text { accuracy if we hold the material. }\end{array}$ \\
\hline
\end{tabular}

Figure 3 - Sample Framework 


\begin{tabular}{|l|c|c|c|c|}
\hline Levels & $\begin{array}{c}\text { UMASS } \\
\text { Medical School } \\
\mathbf{2 0 0 7}\end{array}$ & $\begin{array}{c}\text { UMASS } \\
\text { Medical School } \\
\text { Proposed }\end{array}$ & $\begin{array}{c}\text { New England } \\
\text { Medical Schools } \\
\text { Average }\end{array}$ & $\begin{array}{c}\text { Top U.S. Medical Schools } \\
\text { Outside New England } \\
\text { Average }\end{array}$ \\
\hline & Grades 12-16 & Grades 15, 17, 41 & & $25,592-40,910$ \\
\hline & $23,774-34,216$ & $27,539-40,435$ & $27,999-43,386$ & \\
\hline & & & & \\
\hline & $25,147-36,316$ & & & \\
\hline & & & & \\
\hline & & & & \\
\hline II & $26,187-38,251$ & $30,784-45,344$ & $30,375-48,992$ & \\
\hline & & & & \\
\hline & & & & \\
\hline & $27,539-40,435$ & & & \\
\hline & & & & \\
\hline & & & & \\
\hline III & $29,036-42,972$ & $30,451-55,057$ & $37,360-55,462$ & \\
\hline
\end{tabular}

Figure 4 - Salary Range Comparison

Data collected in 2007. 